\title{
Modeling Wastewater Evolution and Management Options under Variable Land Use Scenarios
}

\author{
Arshad Ashraf, Muhammad Saleem Pomee, \\ Muhammad Munir Ahmad, \\ Muhammad Yasir Waqar and Bashir Ahmad \\ Additional information is available at the end of the chapter
}

http://dx.doi.org/10.5772/60893

\begin{abstract}
The development of a reliable decision support system and predictions for water quantity and quality often require a reasonable level of environmental and hydrological simulations at various geographic scales. The Soil and Water Assessment Tool (SWAT) model offers distributed parameter and continuous time simulation, and flexible watershed configuration and with the adoption of geographic information system (GIS) technology, a user-friendly and interactive decision support system can be developed for wastewater management. In this chapter, we evaluated the spatiotemporal evolution of wastewater contaminants in an environmentally degraded watershed through integrated field-based investigations and modeling approach. Later, management options were identified to improve the watershed health and agro-environment. The results of the modeling study exhibited variable responses of surface runoff and water quality to different scenarios of land use change. Temporal wastewater analysis indicated a significant impact of seasonality on the contaminants' population levels. The adopted approach would prove effective in evaluating better management options to reduce negative impacts of wastewater and contaminants for sustainable agro-environment in future.
\end{abstract}

Keywords: Wastewater modeling, land use scenarios, water policy 


\section{Introduction}

Water is a scarce source in arid and semiarid areas where most of the countries face pressure due to limited opportunities to explore new water resources. This necessitates that all potential unutilized resources of water be used to increase agriculture production. The changes in surface and subsurface flows and land use conditions have direct affect on the downstream in the form of floods and/or water quality deterioration. Climate change and human interference could lead to significant spatio-temporal variations of water quantity, quality, and the associated ecological conditions besides affecting the related management systems [1]. Such complexities force researchers to develop more robust mathematical methods and tools to analyze the relevant information, simulate the related processes, assess the potential impacts/ risks, and generate sound decision alternatives. Spatially meaningful simulation of environmental flows and storages at the catchment scale is essential for predicting water quantity and quality, as well as operational management of the system [2]. There are numerous modeling wastewater efforts undertaken globally by different researchers (e.g., [1, 3-5]), the ultimate focus of which is mainly to mitigate sediment, contaminants, and non-point source nutrient; enhance water quality; and improve sustainability in agricultural production by increasing resilience. Unforeseen and undesirable consequences can result if biophysical and human systems are not examined together [6, 7]. Daloğlu et al. [4] presented a modeling framework that synthesizes social, economic, and ecological aspects of landscape change to evaluate how different agricultural policy and land tenure scenarios and land management preferences affect landscape pattern and downstream water quality. Wrede et al. [3] evaluated the performance of a fully distributed conceptual hydrologic model based on the Hydrologiska Byråns Vattenbalansavdelning (HBV) and Tracer Aided Catchment model-Distributed $\left(\mathrm{TAC}^{\mathrm{D}}\right)$ model concepts in the Central Swedish lowlands. Nesmerak and Blazkova [8] employed a simple transfer function (SISO model) to describe the relationship between the daily total precipitation and the wastewater discharge at the inflow to the wastewater treatment plant (WWTP) for a large city. However, scientific quantifications were required on temporal and spatial scale to identify any feasible wastewater management solution rather than spot and one time sampling of effluents as reported by several studies (e.g., see [9-11]).

The development of a sufficient understanding on which to base decisions or make predictions often requires consideration of a multitude of data of different types and with varying levels of uncertainty [12]. Wastewater contains chemicals such as nitrogen, phosphorus and levels of dissolved oxygen, as well as others that may affect its composition and $\mathrm{pH}$ rating. Agricultural runoff, drainage, as well as inputs from municipal and industrial wastewater often degrade the quantity and quality of surface water bodies. There is a serious need for appropriate water quality monitoring for future planning and management of clean water resources. The SWAT model offers distributed parameter and continuous time simulation, and flexible watershed configuration and with the adoption of GIS technology, a user-friendly and interactive decision support system can be developed for wastewater management. The primary focus of this chapter is to assess the spatio-temporal evolution of wastewater contaminants through the modeling approach and identify management options to improve the watershed health and agro-environment. The findings of the study may support policy makers, researchers, and water managers to make more robust water policy and management options under the changing environment in the future. 


\section{Case study}

In order to develop suitable watershed management strategies, reliable investigation of the watershed problems is necessary. The influence of historical land use evolution on the yield of Rawal watershed lying in the southern Himalayan region was studied to take proactive measures to control the negative impacts of water contaminants in the downstream. The runoff from heavy rains brings a lot of sediments and wastewater from the adjoining areas that increases suspended, as well as bed load in the Korang River and ultimately in the Rawal lake. When the organic nutrients are added to the lake it causes eutrophication-as algal growth increases in the waste, dissolved oxygen concentrations are depleted and increase in sedimentation deteriorates water quality [13]. If wastewater is being discharged into the lake, then the nutrients that are of most important concern are nitrogen and phosphorus. Different studies on the Rawal watershed revealed water quality implications at the lake site. For example, biochemical oxygen demand (BOD) of about $680 \mathrm{mgl}^{-1}$ was reported by Malik [9], while Ahmad et al. [11] reported total dissolve solids (TDS) of dam water from $131 \mathrm{mgl}^{-1}$ to $182 \mathrm{mgl}^{-1}$. The issue of dam water quality is further being aggravated by rapid unplanned urban encroachment in the Rawal watershed area since the last decade. These urban settlements are producing sewage in large quantities that ultimately drain toward the lake through freshwater streams. Since dam water supplies were mainly being used for drinking purpose, therefore, scientific investigation was required to trace the impact of urbanization on Rawal watershed runoff. Because of continuous water quantity and quality degradations primarily due to urban encroachments within the Rawal watershed, there was pressing need for its management on sustainable basis. The emphasis was to mitigate negative water quality implications particularly due to urban sewage. However, scientific quantification of waste flows over a reasonable time frame was essentially required for effective mitigation.

Initially a questionnaire-based detailed survey was undertaken by selecting Bharakaho as a pilot area with specific research motivations, e.g., to investigate water consumption and wastewater disposal systems of selected urban settlement of the Rawal watershed, to quantify temporal and spatial wastewater quality and quantity of selected locations of the settlement using statistical means, and to develop recommendations for the appropriate measures of safe and cost-effective disposal of wastewater. An existing fully calibrated and verified SWAT model of the Rawal watershed [14] was used to simulate nutrient load responses under variable land use scenarios. The model calibration was performed using daily-observed flow data for a 20-year period (2001-2010). Remote sensing (RS) image data was used to analyze the agriculture and urban land use conditions and input to the model for simulating water quality parameters, e.g., sediment, nitrogen, and phosphorus loss from the landscape.

\subsection{Water quality model - SWAT}

The biophysical water quality model-SWAT is a distributed model that integrates land management decisions with soil properties, climate information, and land topography to estimate water quality metrics at the watershed or river basin scale [15]. It is widely used for evaluating and predicting the impacts of conservation practices through simulating the effects 
of climate and land use changes on nutrient and sediment delivery from watersheds [16]. This process-based model (covering multi aspects of hydrology, soil, crop growth, nutrients, sedimentation, pesticides) divides watersheds into sub-basins and hydrologic response units (HRU) as its fundamental computational unit. Runoff flow, sediment, and nutrient loads are calculated separately for each HRU and then summed to determine the total load contribution from each sub-basin [17]. Land management decisions are represented at the HRU scale [4].

Daloğlu et al. [4] studied the impact of plausible future policy and land tenure scenarios on the delivery of available dissolved reactive phosphorus (DRP) and total phosphorus (TP) by exploring links between human and environmental systems. High surface water concentrations of nitrogen and phosphorus are correlated with inputs from fertilizers used for crops [18-20].

\subsection{Description of the study area}

The study area is the watershed of Rawal dam that caters water requirements of the twin cities of Islamabad and Rawalpindi, located in the Northern half of Pakistan (Figure 1). The Rawal watershed has been stretched over an area of about $272 \mathrm{sq} \mathrm{km}$ within longitudes $73^{\circ} 03^{\prime}-73^{\circ}$ $24^{\prime} \mathrm{E}$ and latitudes $33^{\circ} 41^{\prime}-33^{\circ} 54^{\prime} \mathrm{N}$. The area falls under the scrub forest zone and supports mixture composed of Olea ferogenia (Wild Olive), Dodonea viscosa, Crissa spinarum, Acacia modesta [21]. In addition, there exist different grass species in which relative cover of Themeda anathera is maximum. It has been estimated that during an average year, the Rawal watershed area was draining about 84,000 acre-feet of runoff water through four major and 43 minor stream networks [22]. The Rawal dam was constructed over Korang river during 1960 at the toe of Rawal watershed area in Islamabad to harvest runoff water to primarily meet the drinking water requirements of the twin cities. However, land use changes within the Rawal watershed at the cost of deforestation have already affected the storage capacity of the dam. Rapid unplanned urbanization particularly in the lower valleys of the Rawal watershed over the last many years has emerged as major sustainability threat for the dam due to the continuously deteriorating water quality.

According to Ghumman [23], human settlements, deforestation, pesticides, erosion, and wastes from poultry, agricultural activities, and recreational activities are the most possible reasons of contamination of the water of Rawal Lake. Untreated effluents from communal, agricultural, and poultry sectors are seriously damaging the water quality of the lake. In addition to the pollution generated by human activity, the lake also receives natural pollutants that contain the excreta of various wild animal species and fouls that enter the lake via heavy rainfall [24]. Bacteria decompose this organic matter in the presence of oxygen, thus oxygen depletion results in the Eutrophication of the lake. Similarly significant eutrophication is caused by agricultural runoff, concomitant soil erosion, and point-source discharges [25]. The land use patterns within the Rawal watershed have been changed significantly since the 1960's and major catchment area has been deforested to accommodate the rapidly increasing urban population of Islamabad - the capital city of Pakistan-and other infrastructural developments. During 18-year period (from 1992 to 2010), about 53\% of Rawal watershed land use has been changed [26]. The changed land use features altered watershed hydrology and conse- 


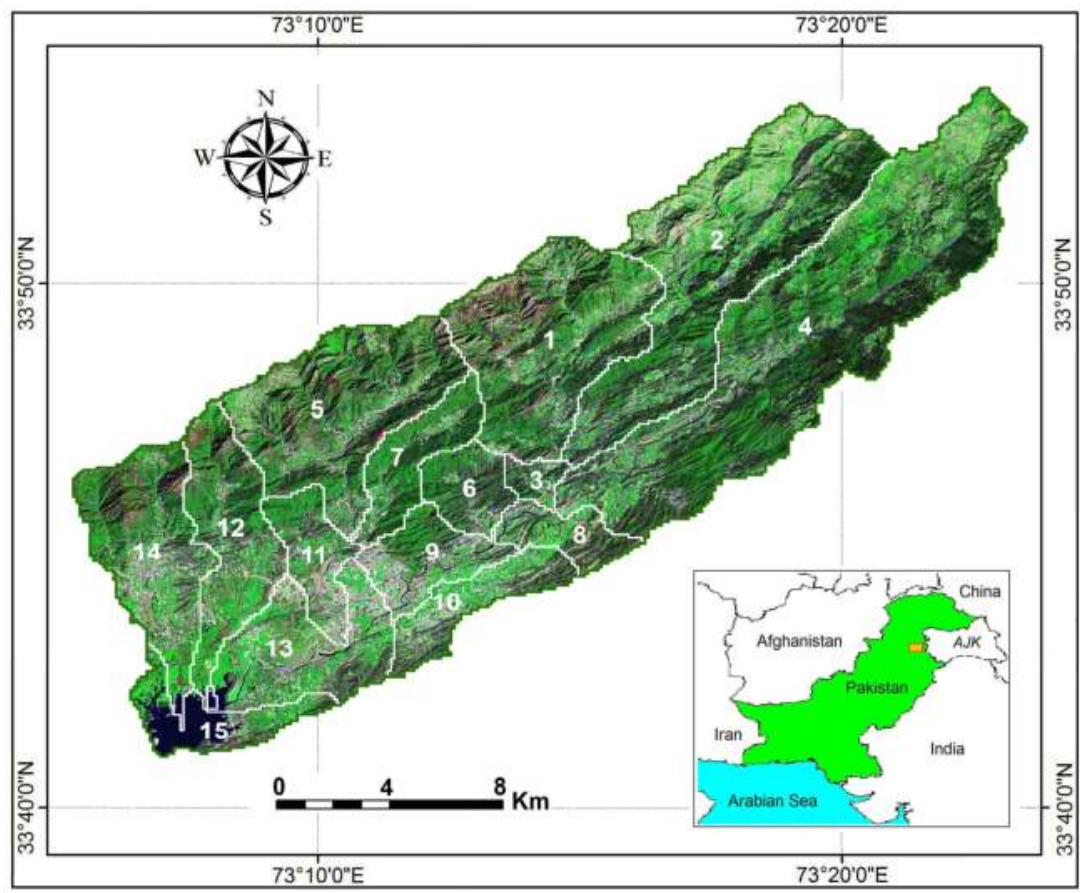

Figure 1. Location of Rawal watershed and its sub-basins.

quently the designed storage capacity of Rawal dam (47,500 acre -feet at the time of construction) has been decreased to around 31,000 acre feet [27]. Moreover, the increased urbanization, commercial, and agricultural developments within the Rawal watershed area has also significantly deteriorated the water quality [24]. Agricultural runoff results in algal blooms, poor water clarity, and summer hypoxia (low oxygen) [28-30] that generally impact fisheries, recreation, and drinking water [31].

Bharakaho, located at about $5 \mathrm{~km}$ from the dam site within the Rawal watershed, was selected as a surveyed site for the present study. It is the largest urban setting in the watershed. The study sub-watershed comprises of five catchments that ultimately drain into Korang river. The selected catchments were: i) Shahdara catchment (before the bridge on Murree road), ii) Colonel Amanullah road catchment, iii) Hathala catchment, IV) Kiani road catchment and Shahdara catchment (After bridge on Murree road).

\section{Material and methods}

In order to evaluate water quality response to varying land use changes in the Rawal watershed through hydrological modeling, satellite remote sensing data of Landsat ETM+ (Enhanced Thematic Mapper plus) of 2010 period was used in the present study. 


\subsection{Preparation for model input data}

The image was classified into seven land use/land cover classes, e.g., conifer forest, scrub forest, agriculture land, rangeland, bare soil, built-up land, and water bodies. The image classification was undertaken using the maximum likelihood rule, which provides reliable classification results [26]. Rainfall-runoff model SWAT was calibrated for the target watershed. The statistical measures, such as coefficient of determination $\left(R^{2}\right)$ and Nash-Suttchiffe Simulation Efficiency $\left(E_{w s}\right)$, were used to evaluate model prediction. The $R^{2}$ value is an indicator of strength of relationship between the observed and simulated values, while the latter coefficient indicates how well the plot of observed versus simulated value fits the 1:1 line.

\subsection{Wastewater sampling strategy}

To complement wastewater related quantifications, a wastewater sampling study was designed by selecting Bharakaho sub-watershed due to its highest population density; rapid urbanization rate, location near to dam site, and existence of significant commercial and industrial activities, thus posing high potential of wastewater yield. Wastewater quality was monitored continuously for over 14 months in terms of eight parameters and results were analyzed in temporal and spatial context. Advanced statistical tools were employed to further investigate significance levels for temporal and spatial variability. The quantifications of wastewater pollution were performed using empirical relationships for domestic, industrial, and commercial land uses. Review of available wastewater management related options was made and based on a robustly developed criterion, the feasible option was recommended. Five catchments and their drainage pattern were delineated in Bharakaho sub-watershed using GIS tools. The sampling points were selected based upon physical surveys at outlets of these catchments (Figure 2), the particulars of which are shown in Table 1.

\begin{tabular}{|c|c|c|c|}
\hline Location & Geographic Coordinates & Area (ha) & $\begin{array}{c}\text { Total Industrial and Commercial } \\
\text { Activities }\end{array}$ \\
\hline $\begin{array}{l}\text { Shahdara catchment (Before } \\
\text { bridge on Murree road) }\end{array}$ & $\begin{array}{l}73^{\circ} 10^{\prime} 23.7128^{\prime \prime} \mathrm{E} \\
33^{\circ} 44^{\prime} 12.0721^{\prime \prime} \mathrm{N}\end{array}$ & 132 & 3 \\
\hline Col. Amanullah Road catchment & $\begin{array}{l}73^{\circ} 10^{\prime} 23.7128^{\prime \prime} \mathrm{E} \\
33^{\circ} 44^{\prime} 13.0822^{\prime \prime} \mathrm{N}\end{array}$ & 25 & 7 \\
\hline Hathala catchment & $\begin{array}{l}73^{\circ} 11^{\prime} 38.9016^{\prime \prime} \mathrm{E} \\
33^{\circ} 44^{\prime} 38.2142^{\prime \prime} \mathrm{N}\end{array}$ & 169 & 20 \\
\hline Kiani road catchment & $\begin{array}{l}73^{\circ} 10^{\prime} 42.1186^{\prime \prime} \mathrm{E} \\
33^{\circ} 43^{\prime} 35.1740^{\prime \prime} \mathrm{N}\end{array}$ & 189 & 19 \\
\hline $\begin{array}{l}\text { Shahdara catchment (After bridge } \\
\text { on Murree road) }\end{array}$ & $\begin{array}{l}73^{\circ} 10^{\prime} 37.0289^{\prime \prime} \mathrm{E} \\
33^{\circ} 43^{\prime} 29.6024^{\prime \prime} \mathrm{N}\end{array}$ & 160 & 11 \\
\hline
\end{tabular}

Table 1. Location of sampling points and type of activities in the study area. 


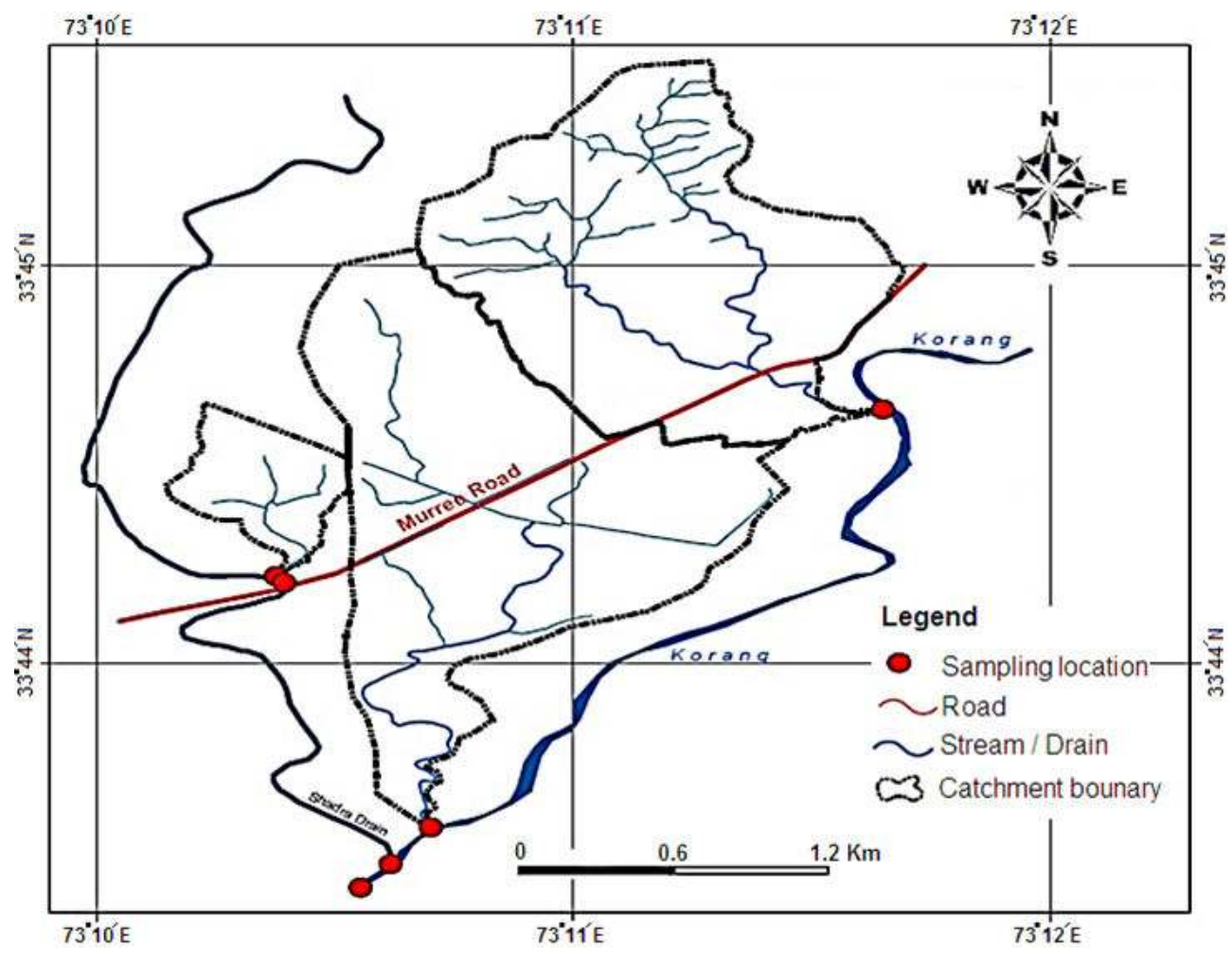

Figure 2. Location of sampling points in Bharakaho sub-watershed.

To analyze wastewater implications, extensive review was made. The critical parameters related wastewaters associated with urbanization selected for monitoring purposes are: Biochemical Oxygen Demand (BOD); Chemical Oxygen Demand (COD); Electrical Conductivity (EC); $\mathrm{pH}$; Total Dissolve Solids (TDS); Total Phosphorous (TP); Nitrate $\left(\mathrm{NO}_{2}\right)$; and Nitrite $\left(\mathrm{NO}_{3}\right)$. Monthly sampling frequency was used to collect waste samples and accredited laboratory of PCRWR-Islamabad was used for analysis purpose. Statistical tools were used to test the spatial and temporal variations of wastewater in the study area. Average daily waste flows from each catchment of Bharakaho generated from different sources were estimated by using different empirical relationships as described below.

\subsubsection{Domestic waste flow estimations}

The relationship in Eq. 1 was used for the estimation of domestic waste flow from the study area.

$$
\mathrm{Q}_{\mathrm{DW}}=\mathrm{P}_{\mathrm{t}} \times \mathrm{q}
$$


Where

$\mathrm{Q}_{\mathrm{DW}}=$ Domestic Sewage Flow (lit/day)

$\mathrm{P}_{\mathrm{t}}=$ Total Population of the Area

$\mathrm{Q}=$ Average daily per capita water use (lit/day)

$75 \%$ of water supply was assumed to be returning as sewage as suggested by Vesilind [32].

\subsubsection{Industrial waste flow estimations}

Industrial waste estimation was inclusive of i) waste generated per employee (17.5 GD-1) and ii) waste generated per square foot $\left(0.18 \mathrm{GD}^{-1}\right)$ as recommended by the University of Minnesota [33].

Total industrial waste generation per day from industrial campus $=$ Waste generated by employees + Waste generated from total area:

$$
\mathrm{W}_{\mathrm{TI}}=\mathrm{W}_{\mathrm{E}}+\mathrm{W}_{\mathrm{TA}}
$$

Where

$\mathrm{W}_{\mathrm{TI}}=$ Total industrial waste generation per day from industrial campus (unit)

$\mathrm{W}_{\mathrm{E}}=$ Waste generated by employees (unit)

$\mathrm{W}_{\mathrm{TA}}=$ Waste generated from total area (unit)

\subsubsection{Commercial waste flow estimation}

Commercial waste flow estimation was dependent upon type of commercial activity. For example, from hospitals, the waste flow was estimated using following formula after [33]:

Total waste generated from hospitals $=$ Waste generated by patients + Waste generated by practitioners + Waste generated from total area

Waste generate per patient $=3 \mathrm{GD}^{-1}$

The number of patients was known by visiting hospitals.

Waste generated by practitioners $=$ Waste generated per practitioner $\times$ Number of practitioners Waste generated per practitioner $=275 \mathrm{GD}^{-1}[33]$

The number of practitioners is known by visiting hospitals.

Waste generated from total area $=$ Waste generated per square foot $\mathrm{x}$ Area of commercial activity

Waste generated per square foot $=1.1 \mathrm{GD}^{-1}[33]$ 
Area of commercial activity is known through visiting the commercial activity. Similarly, wastes are generated from all commercial activities. The waste is often extensive in few drains depending upon the urban development in the area (Figure 3).

Average daily waste loading (organic and inorganic) was estimated to quantify the amount of waste being generated from the study area, so that proper wastewater treatment technology can be recommended for the area. Wastewater treatment options were analyzed and a criterion was developed that included costs (capital, operating, and maintenance), technology, manpower, climatic conditions, and community interactions.
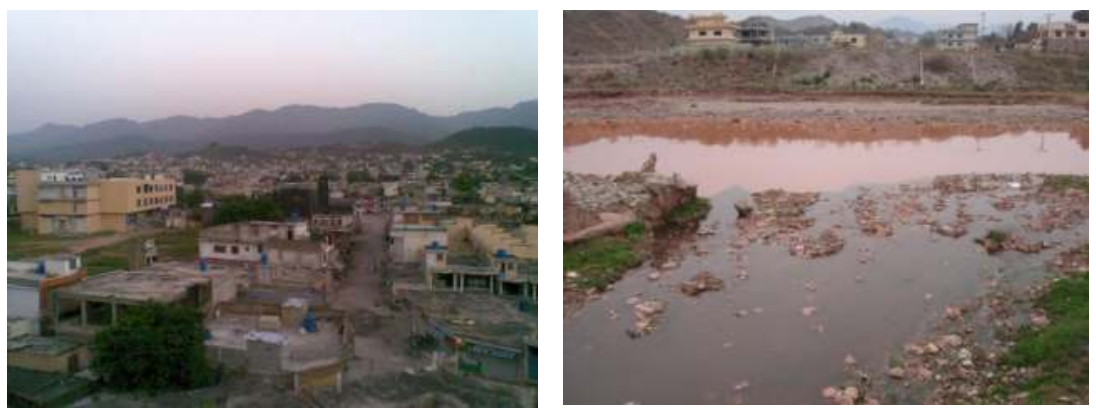

Figure 3. Urbanization in Bharakahu (left) and wastewater from Hathala drain entering Korang River (right).

\section{Results and discussion}

\subsection{Water and wastewater discharge pattern}

Through questionnaire-based surveys conducted in the pilot area of Bharakaho, information related to water supply, drainage mode, water consumption patterns, and existing wastewater systems were gathered. In majority of the area (about $60 \%$ ), groundwater was the major source of water supply followed by surface-tapped water from Simly dam $(26.3 \%)$ for domestic needs (Figure 4). While a few were using both surface and sub-surface water supplies for domestic purpose $(6.3 \%)$. When inquired about average water consumption, majority was using 100 200 liters of water per person per day $(56.6 \%)$, while significant proportion of inhabitants (21.7\%) also reported less than 100 liter/day/person water consumption. Some also were lucky enough to have excess of more than 300 liters. This trend overall suggested that water scarcity was not an issue and people were getting quite handsome amount of water supply. When inquired about waste domestic drainage mode, more than half of the population was using buried pipe lines $(62.3 \%)$, while $32.6 \%$ people were using open drains to discharge wastewaters out of homes. Further, it was revealed that almost entire population was using septic tanks as a means of preliminary treatment. Further analysis indicated that combined sewer system was prevailing in the area (95\%) and awareness regarding untreated wastewater discharges into freshwater streams was very high $(77 \%)$. While interesting to note was the fact that majority (about $71 \%$ ) were willing to pay for wastewater treatment facilities if provided. 

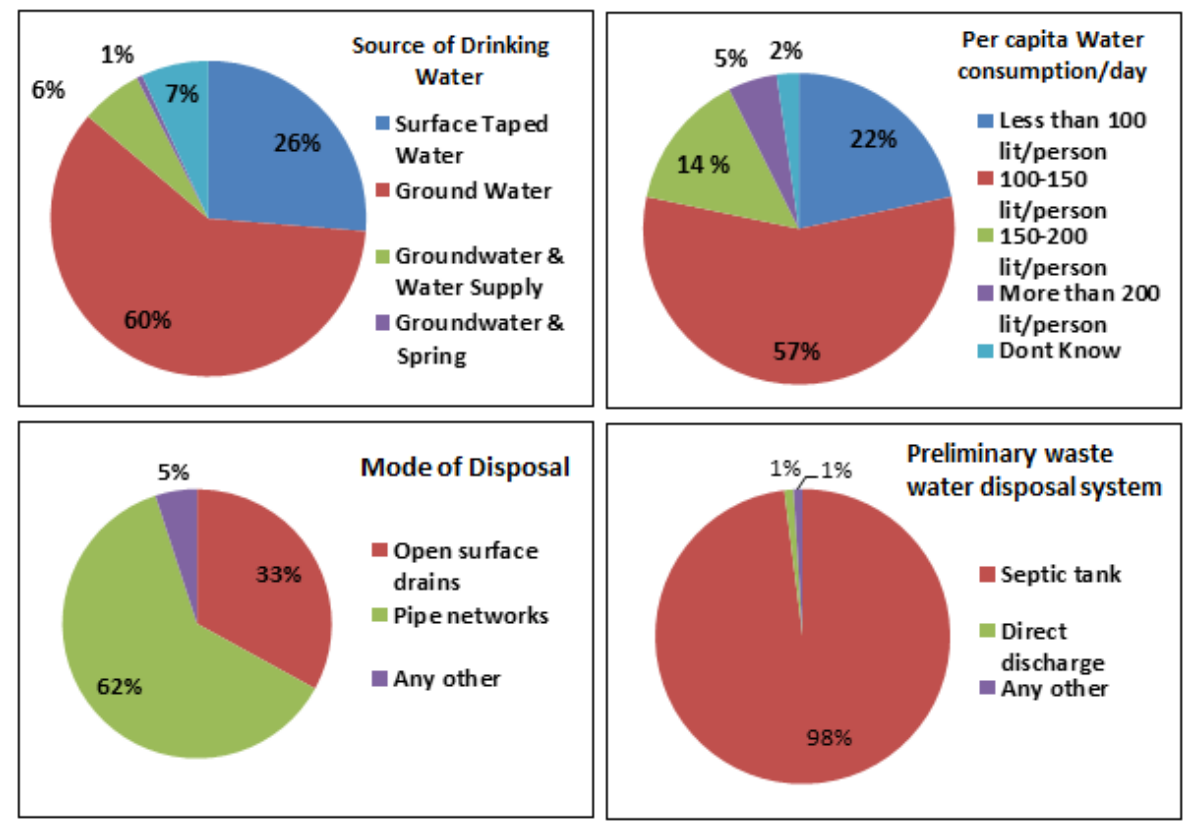

Figure 4. Water consumption and discharge patterns in the studied catchments of Bharakaho.

\subsection{Wastewater production potential}

Wastewater was not only being produced from domestic sources but there were significant industrial (construction, marble industry, and commercial activities from hospitals, markets, school, etc.) sources within the study area that were also consuming fresh water supplies and discharging wastewaters into freshwater streams. The estimated wastewater production potential per day from all these sources has been summarized in Table 2. Out of 6.354 million gallons per day (MGD) waste flow discharging from the study area, $97.4 \%$ was being added from the domestic sources, while $2.6 \%$ was contributed by industrial and commercial sources. It increases significantly at each step as river water approaches towards the lake. The Kiani road catchment was producing most non-domestic sewage flows (0.63 MGD), while it was also thickly populated area and producing highest levels of domestic sewage (2.377 MGD) followed by Hathala catchment (1.783 MGD). The wastewater sampling results are shown in Table 3. The values were averaged over 14 months of study period.

The permissible limits of various wastewater parameters for Pakistan are depicted in Table 4. These limits of the parameters are National Environment Quality (NEQ) standards for wastewater parameters to be discharged in water or on land [34]. By comparing the actual parametric values with the NEQ standards, it is obvious that Shahdara (before bridge), Col. Amanullah road, and Hathala catcments were discharging BOD more than permissible levels, while COD was only exceeding for Hathala catchment and all other parameters were within 


\begin{tabular}{cccc}
\hline Location & $\begin{array}{c}\text { Domestic Waste } \\
\text { (MGD) }\end{array}$ & $\begin{array}{c}\text { Industrial and Commercial } \\
\text { Waste (MGD) }\end{array}$ & $\begin{array}{c}\text { Total Waste } \\
\text { (MGD) }\end{array}$ \\
\hline Shahdara catchment (Before bridge) & 0.470 & 0.005 & 0.475 \\
\hline Col. Amanullah Road catchment & 0.966 & 0.014 & 0.980 \\
\hline Hathala catchment & 1.783 & 0.041 & 2.440 \\
\hline Kiani road catchment & 2.377 & 0.063 & 0.635 \\
\hline Shahdara catchment (After bridge) & 0.594 & 0.041 & 6.354 \\
\hline
\end{tabular}

Table 2. Wastewater production potential from different sources in the study area.

permissible limits. However, these standards were for wastewaters, while the storage of Rawal dam was being used for drinking purposes, which required zero BOD levels, and for that reason this was unfit water.

Once waste flow rates and concentrations of pollutants were estimated, the actual water loading rates in freshwater streams were calculated (Table 5). A net BOD of 2,296 kg day ${ }^{-1}$ and COD of $3,875 \mathrm{~kg}$ day $^{-1}$ were being discharged from the area, which was considered very high. Nitrate was being discharge at highest levels $\left(141 \mathrm{~kg} \mathrm{day}^{-1}\right)$, followed by phosphorus related pollutants $\left(53 \mathrm{~kg} \mathrm{day}^{-1}\right)$, while TDS were being added at the rate of $19,653 \mathrm{~kg} \mathrm{day}^{-1}$ through the study area via domestic, commercial, and industrials means (Table 5). The data indicated that spatial variability was also prevalent in the study area. For example, Col. Amanullah catchment was highly polluted due to higher values of BOD and COD (dense population and closed nature of catchment has reduced surface runoff from outside non-urbanized area), while Shahdara catchment (after bridge) was least problematic due to having large open rangeland/ vegetation cover in the catchment. According to Kahlown et al. [35] increase in population has significant effect on the water quantity and quality as the increase in population is a cause of increase in contaminants and some other wastewater parameters.

\begin{tabular}{ccccccccc}
\hline Location & $\begin{array}{c}\text { BOD } \\
(\mathbf{p p m})\end{array}$ & $\begin{array}{c}\text { COD } \\
(\mathrm{ppm})\end{array}$ & $\mathrm{pH}$ & $\begin{array}{c}\text { EC } \\
\left.(\mu \mathrm{Scm})^{-1}\right)\end{array}$ & $\begin{array}{c}\text { TP } \\
(\mathrm{ppm})\end{array}$ & $\begin{array}{c}\text { Nitrate } \\
(\mathrm{ppm})\end{array}$ & $\begin{array}{c}\text { Nitrite } \\
(\mathrm{ppm})\end{array}$ & $\begin{array}{c}\text { TDS } \\
(\mathrm{ppm})\end{array}$ \\
\hline $\begin{array}{c}\text { Shahdara catchment } \\
\text { (before bridge) }\end{array}$ & 52 & 16 & 7.29 & 359 & 0.45 & 4 & 0.89 & 209 \\
\hline $\begin{array}{c}\text { Col. Amanullah road } \\
\text { catchment }\end{array}$ & 74 & 66 & 7.06 & 525 & 1.35 & 2 & 0.045 & 315 \\
\hline Hathala catchment & 112 & 143 & 6.93 & 631 & 0.68 & 3 & 0.015 & 378 \\
\hline Kiani road catchment & 48 & 36 & 6.95 & 617 & 1.15 & 8.5 & 1.875 & 371 \\
\hline $\begin{array}{c}\text { Shahdara catchment } \\
\text { (after bridge) }\end{array}$ & 3 & 3 & 7.09 & 400 & 0.33 & 4.5 & 1.675 & 239 \\
\hline
\end{tabular}

Table 3. Average pollution loadings from the study area. 


\begin{tabular}{ll}
\hline Wastewater Parameters & Permissible Limits \\
\hline Biochemical Oxygen Demand & $50 \mathrm{mgl}^{-1}$ \\
\hline Chemical Oxygen Demand & $100 \mathrm{mgl}^{-1}$ \\
\hline Electrical Conductivity & $1,000 \mu \mathrm{Scm}^{-1}$ \\
\hline $\mathrm{pH}$ & $6.0-8.0$ \\
\hline Nitrate & $20 \mathrm{mgl}^{-1}$ \\
\hline Nitrite & $2 \mathrm{mgl}^{-1}$ \\
\hline Total Phosphates & $10 \mathrm{mgl}^{-1}$ \\
\hline Total Dissolved Solids & $1,200 \mathrm{mgl}^{-1}$ \\
\hline
\end{tabular}

Table 4. Permissible limits of wastewater parameters as per NEQ standards.

\begin{tabular}{|c|c|c|c|c|c|c|}
\hline Locations & $\begin{array}{c}\text { BOD } \\
\text { (kg.day-1) }^{-1}\end{array}$ & $\begin{array}{c}\text { COD } \\
\left(k^{2} \cdot \text { day }^{-1}\right)\end{array}$ & $\begin{array}{c}\text { TP } \\
\left(\text { kg.day }^{-1}\right)\end{array}$ & $\begin{array}{c}\text { Nitrate } \\
\left(\text { kg.day }^{-1}\right)\end{array}$ & $\begin{array}{c}\text { Nitrite } \\
\left(\text { kg.day }^{-1}\right)\end{array}$ & $\begin{array}{c}\text { TDS } \\
\left(\text { kg.day }^{-1}\right)\end{array}$ \\
\hline Shahdara catchment (before bridge) & 98 & 158 & 3 & 6 & 0.17 & 963 \\
\hline Col. Amanullah Road catchment & 680 & 1117 & 11 & 30 & 0.29 & 2,961 \\
\hline Hathala catchment & 547 & 1052 & 16 & 50 & 7.25 & 6,649 \\
\hline Kiani road catchment & 940 & 1513 & 22 & 49 & 1.29 & 8,225 \\
\hline Shahdara catchment (after bridge) & 31 & 35 & 1 & 6 & 1.73 & 855 \\
\hline Total & 2,296 & 3,875 & 53 & 141 & 4.73 & 19,653 \\
\hline
\end{tabular}

Table 5. Estimated loading rates of BOD, COD, TP, Nitrate, Nitrite, and TDS.

Pollution parameters such as BOD, COD, phosphates, and TDS were being discharged in large quantities $\left(940,1513,22\right.$, and 8,225 kg.day ${ }^{-1}$ respectively) from Kiani road catchment, while nitrate $\left(50 \mathrm{~kg}\right.$.day $\left.{ }^{-1}\right)$ and nitrite were being added $\left(7.25 \mathrm{~kg}\right.$.day $\left.{ }^{-1}\right)$ from the Hathala catchment. The values of all these parameters were lowest in the Shahdara catchment.

\subsection{Impact of seasonality on wastewater}

Careful analysis of rainfall and pollution loading rates (BOD \& COD) were following reverse interaction throughout the study period. The rainfall recorded in Satrameel field station located in the study area has shown an increasing pattern during monsoon months from July to September (Figure 5). The lowest values for both BOD and COD were observed during the wet period of monsoon when increased surface runoff diluted the pollutions (least in September), while higher concentrations were recorded during dry periods (highest during March) when after monsoon even base flows started decreasing (Figure 6). Although higher rainfalls during June to September 2011 had caused a lot of surface runoff that resulted in lowering of the pollution levels, nitrate and nitrite increased in amount due to the washing out of human, poultry, and animal wastes. 


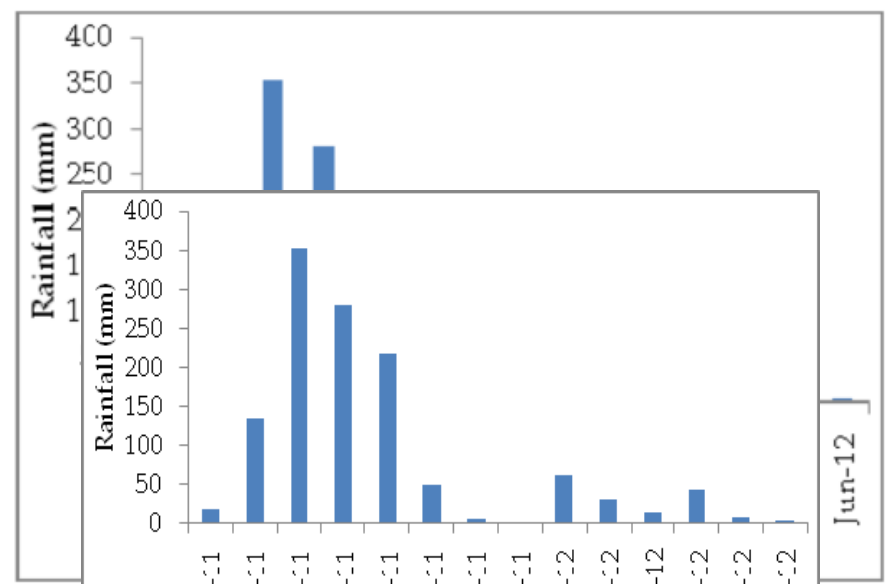

Figure 5. Monthly rainfall pattern during study period.
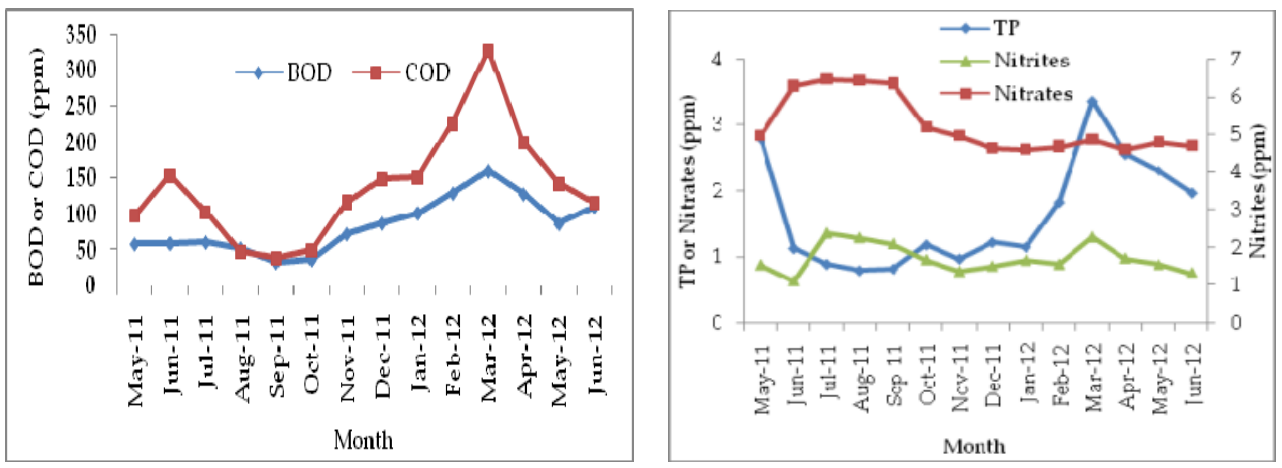

Figure 6. Temporal behavior of BOD, COD, TP, nitrite, and nitrate in the study area.

To trace seasonality, further analysis was carried out and outcome of BOD and COD is shown in Figure 7. Seasonality has indicated a clear impact on both selected parameters during study during wet period of Monsoon increased freshwater surface runoff in natural streams caused significant dilution and consequently reduced concentrations of BOD and COD were observed for all locations. While in contrary, during non-monsoon periods, the corresponding values were much higher for respective catchments. Similarly, the other pollution parameters were also analyzed in context of seasonality (Table 6). A close insight of both tables revealed that generally $\mathrm{pH}$ increased with rains (monsoon) mainly because runoff waters brought large quantities of wastes, while phosphorus and nitrate increased at some catchments during monsoon due to increased transport of nutrients with runoff water. EC, on the other hand, decreased during the monsoon period due to dilution impact. 

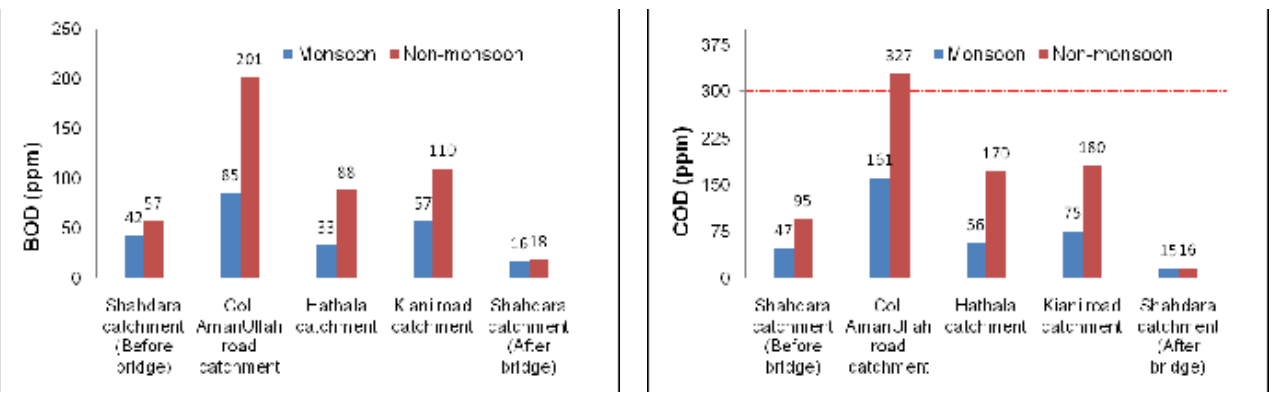

Figure 7. Spatial variability of BOD and COD during monsoon and non-monsoon periods.

\begin{tabular}{|c|c|c|c|c|c|c|c|c|}
\hline \multirow[b]{2}{*}{ Location } & \multicolumn{2}{|c|}{$\mathrm{EC}\left(\mu \mathrm{Scm}^{-1}\right)$} & \multicolumn{2}{|c|}{ TP (ppm) } & \multicolumn{2}{|c|}{ Nitrate (ppm) } & \multicolumn{2}{|c|}{ Nitrite (ppm) } \\
\hline & Monsoon & $\begin{array}{c}\text { Non- } \\
\text { monsoon }\end{array}$ & Monsoon & $\begin{array}{c}\text { Non- } \\
\text { monsoon }\end{array}$ & Monsoon & $\begin{array}{c}\text { Non- } \\
\text { monsoon }\end{array}$ & Monsoon & $\begin{array}{c}\text { Non- } \\
\text { monsoon }\end{array}$ \\
\hline $\begin{array}{c}\text { Shahdara } \\
\text { catchment } \\
\text { (before bridge) }\end{array}$ & 762 & 926 & 1.1 & 1.61 & 3.5 & 3.6 & 0.03 & 0.11 \\
\hline $\begin{array}{c}\text { Col. } \\
\text { Amanullah } \\
\text { road catchment }\end{array}$ & 1,303 & 1,343 & 3.25 & 2.6 & 5 & 8.73 & 0.06 & 0.08 \\
\hline $\begin{array}{c}\text { Hathala } \\
\text { catchment }\end{array}$ & 1,410 & 1,793 & 1.7 & 2.25 & 10.5 & 6.59 & 4.69 & 0.39 \\
\hline $\begin{array}{l}\text { Kiani road } \\
\text { catchment }\end{array}$ & 1,226 & 1,468 & 2.71 & 2.39 & 4.75 & 5.46 & 0.6 & 0.05 \\
\hline $\begin{array}{l}\text { Shahdara } \\
\text { catchment } \\
\text { (after bridge) }\end{array}$ & 580 & 595 & 0.75 & 0.25 & 4.1 & 2.33 & 0.11 & 0.82 \\
\hline
\end{tabular}

Table 6. Impact of seasonality on EC, TP, nitrate, and nitrite.

Statistical analysis of One-Way ANOVA technique was employed to determine significance of seasonality for various parameters. BOD indicated higher values of $\mathrm{P}(>0.1)$ and coefficient of variance $(\mathrm{CV}=105.3)$ for temporal scale and lowest values $(\mathrm{P}<0.05 \& \mathrm{CV}=73.2)$ for spatial scale exhibiting more variability with space than time. Similar trends were also found for COD and other major parameters. However, $\mathrm{pH}$ varied both spatially and temporally while Nitrites were neither temporally not spatially varied.

\subsection{Water quality response to land use change scenarios}

There have been occurred extensive land use changes in the watershed during the last two decades resulting from deforestation and high growth in the urbanization [14]. The responses of sediment yield and water quality parameters, e.g., soluble $\mathrm{N}$ and $\mathrm{P}$ and nitrate contribution 
to reach, to changes in the land use were studied. The land use/land cover extent estimated in Rawal watershed during base year and under various scenarios is shown in Table 7. These scenarios are intended to be prospective and informative rather than projective or prescriptive of the future [36]. Scenario-1 is related to deforestation case in which all the scrub forest is assumed to be converted into rangeland (the rangeland increases to $75.5 \%$ ). The natural forests in the country have been subjected to deforestation for growing agricultural crops, grazing domestic animals, and obtaining fuel wood and timber for the last many years [37]. The extensive grazing and cutting of wood have deformed the plants into bushes [21]. Scenario-2 represents the case of increase in agricultural development and growth in cropping activities. All the rangeland of base year is assumed to be converted into agriculture land (the agriculture land increases to $44.1 \%$ ) in this scenario. Non-point sources particularly from agriculture are generally the major causes of nutrient pollution [38]. Scenario-3 is related to case of growth in urbanization under which all the rangeland of base year is assumed to be converted into builtup land, i.e., it increases to $45.6 \%$ in the watershed.

In scenario- 1 , the surface runoff has shown an average increase of about $0.9 \%$, while sediment yield increases by about $26 \%$ from that of the base year 2010. The organic N and P exhibit more or less same positive change of about $23 \%$ in this scenario. The contribution of nitrate to stream flow increases slightly (about 1\%) due to degradation of the scrub forest.

In scenario-2, the surface runoff indicates an increase ranging between $0-10.1 \%$, while sediment yield increases on an average by about $21 \%$. The organic $\mathrm{N}$ exhibits an average decrease of about $1.9 \%$, while organic $\mathrm{P}$ increases by $3.6 \%$ due to growth in the agriculture developments. The contribution of nitrate to stream flow increases on an average by $2.4 \%$ in the watershed (Table 8).

\begin{tabular}{ccccc}
\hline Land use & Base year & Senario-1 & Senario-2 & Senario-3 \\
\hline Conifer & 2.3 & 2.3 & 2.3 & 3.3 \\
\hline Scrub & 38.8 & 0 & 38.8 & 7.4 \\
\hline Agriculture & 7.4 & 7.4 & 44.1 & 0 \\
\hline Rangeland & 36.7 & 75.5 & 0 & 4.8 \\
\hline Soil/Rocks & 4.8 & 4.8 & 8.8 & 45.6 \\
\hline Settlement & 8.9 & 8.9 & 1.1 & 1.1 \\
\hline Water & 1.1 & 1.1 & 100 & 100 \\
\hline Total & 100 & 100 & 8.9 \\
\hline
\end{tabular}

Table 7. Percentage extent of land use/land cover in base year and under various land use scenarios.

The surface runoff has shown an increase of about $3.1 \%$ in scenario-3, likely due to expansion in the imperviousness. The upper sub-basins of the watershed indicate an increase in the surface runoff under scenarios -2 and -3 , the runoff being higher in the later scenario due to urban development (Figure 8). There is a minor decrease in the sediment yield (about $4.1 \%$ ) 
in scenario-3 that may be attributed to the decrease in the rangeland, e.g., grass/shrubs that is replaced by the built-up land. The increase in the sediment yield is prominent under scenarios -1 and -2 (the cases of deforestation and agriculture development) particularly in the upper sub-basins (Figure 9). In scenario-3, the contribution of nitrate to stream flows shows a slight increase from that of scenario-2, overall presenting an identical picture of distribution in different sub-basins of the watershed under these two scenarios (Figure 10).

\begin{tabular}{ccccccc}
\hline \multirow{2}{*}{ Scenario } & Parameter & SURQ & SYLD & NSURQ & ORGN & ORGP \\
\hline \multirow{3}{*}{1} & Max & 4.311 & 165.759 & 5.247 & 129.144 & 128.692 \\
\cline { 2 - 6 } & Min & 0.000 & 0.000 & 0.000 & 0.000 & 0.000 \\
\cline { 2 - 6 } & Average & 0.869 & 26.337 & 1.045 & 23.422 & 23.167 \\
\hline \multirow{2}{*}{2} & Max & 10.086 & 112.104 & 11.485 & 0.000 & 20.659 \\
\cline { 2 - 6 } & Min & 0.000 & 0.000 & 0.000 & -16.218 & 0.000 \\
\hline \multirow{2}{*}{3} & Average & 2.128 & 20.994 & 2.407 & -1.919 & 3.609 \\
\hline & Max & 14.375 & 0.000 & 12.509 & 0.000 & 0.000 \\
\hline & Min & 0.000 & -30.002 & 0.000 & -27.725 & -27.057 \\
\hline
\end{tabular}

SURQ = Surface runoff; SYLD = Sediment yield; ORGN = Organic-Nitrogen; ORGP = Organic Phosphorus; and NSURQ = Nitrate contribution to stream flow

Table 8. Percentage change in the water quality parameters from that of base year.

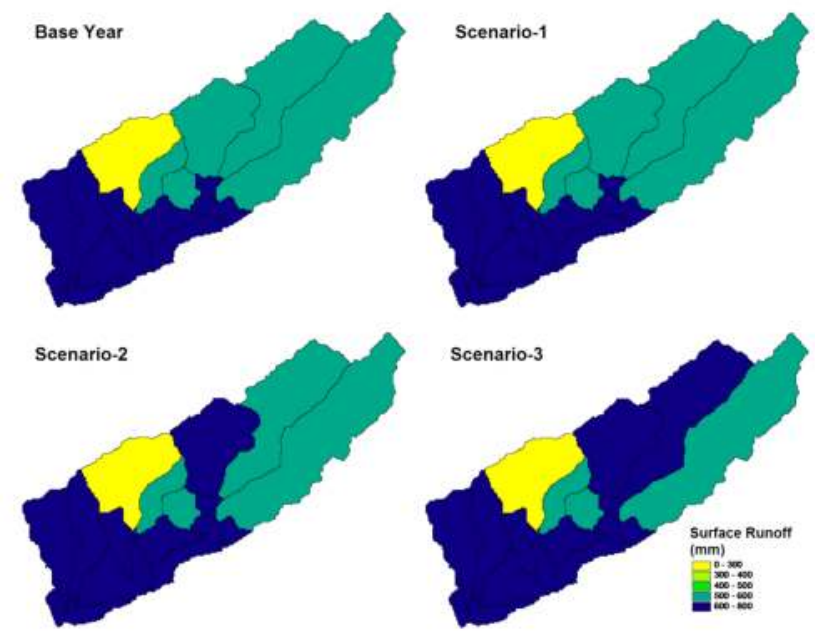

Figure 8. Surface runoff under various scenarios of land use change. 
The changes in various parameters in the watershed under three scenarios are shown in Figures $8-12$. The organic $\mathrm{N}$ and $\mathrm{P}$ indicate an average decrease of about $4 \%$ likely due to growth in urbanization in scenario-3. The results of organic $\mathrm{N}$ are similar to scenario-2 but differ from scenario- 1 that indicates a positive change in the upper sub-basins of the watershed (Figure 11). The changes in organic $P$ are diverse in various sub-basins under all three scenarios, being less significant under scenario-3 due to high growth in the urbanization (Figure 12).
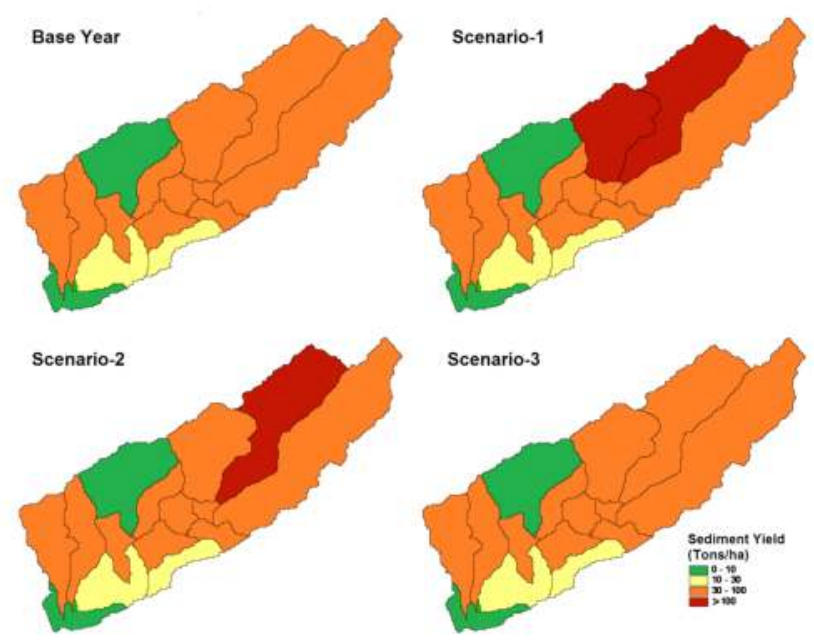

Figure 9. Sediment yield under various scenarios of land use change.
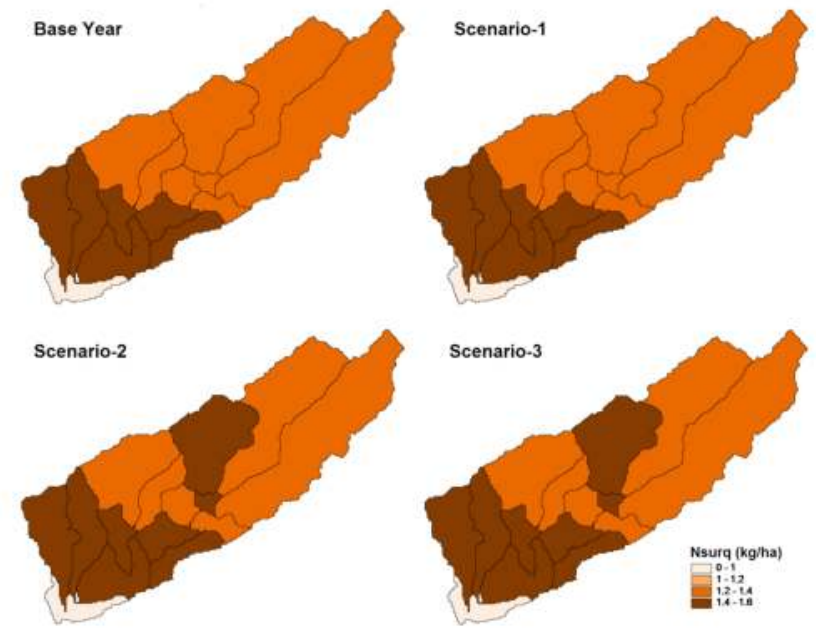

Figure 10. Contribution of nitrate to reach in different sub-basins of the watershed. 

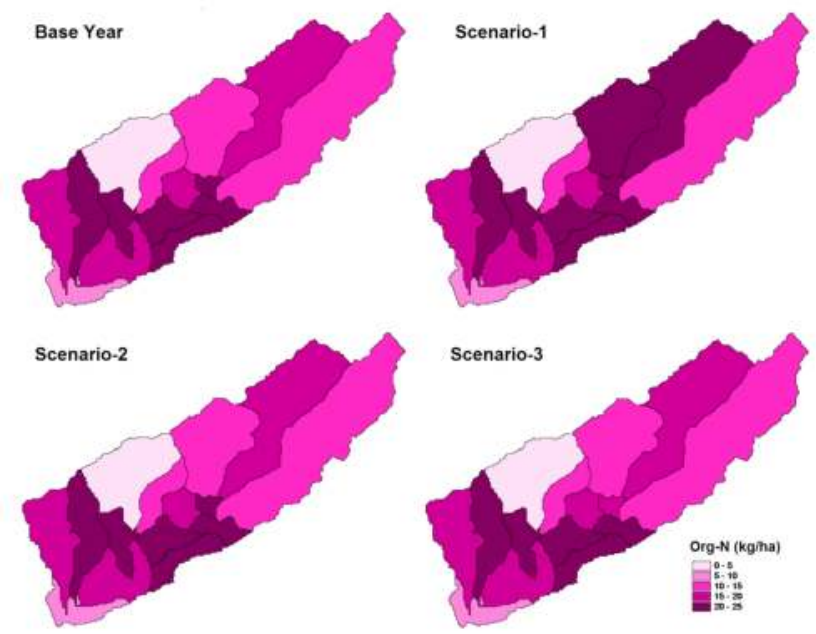

Figure 11. Organic nitrate generated under various scenarios.
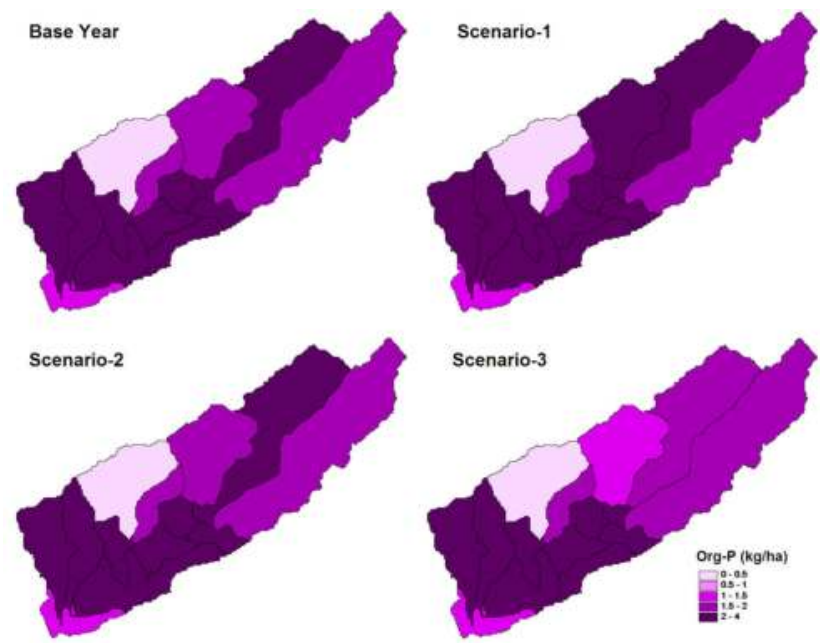

Figure 12. Organic phosphorous generated in different sub-basins under three scenarios.

\subsection{Selection of appropriate wastewater treatment technology}

Properly planned use of municipal wastewater alleviates surface water pollution problems and not only conserves valuable water resources but also takes advantage of the nutrients contained in sewage to grow crops. Based upon the above analysis, it was evident that 
untreated wastewater discharge towards Rawal dam was a serious issue due to drinking nature of the storage and remedies were essential. A scientifically designed septic tank with multiple compartments was considered to be the most feasible wastewater management solution due to typical geographical and socio-economic conditions of the study area. Although over $98 \%$ area, already these were prevailing but these were just dug holes without considering any scientific justifications. If a properly planned septic tank could be developed and replaced in entire area, it can reduce the wastewater contamination issue at Rawal dam very significantly. As septic tanks can be $60 \%-70 \%$ efficient in reducing wastewater loads, dilution through freshwaters from Rawal watershed area will help in mitigating remaining impurities. To address these issues, conservation practices, such as conservation tillage, filter strips, land retirement, and nutrient management can be adopted [25]. Other policy level planning should be to (a) encourage reduction, recycling, and reuse of municipal and industrial solid and liquid wastes; (b) develop and enforce rules and regulations for proper management of municipal, industrial, hazardous, and hospital wastes; (c) develop environmental risk assessment guidelines for existing industries as well as new development interventions; and (d) adopt cleaner technology, implement pollution control measures, and compliance with the environmental standards.

\section{Conclusions}

The issues related to water quality and quantity management involves numerous technical, socio-economic and environmental factors and coupled with complex spatial variability become highly complicated. The results of the integrated field based investigations and modeling approach exhibited variable responses of surface runoff and water quality to changing conditions of urbanization and deforestation. The concentration of the pollution parameters was found higher from the densely populated catchments containing extensive industrial and commercial activities. Temporal wastewater analysis indicated a significant impact of seasonality on the contaminants' population levels. The wet season of monsoon (July-September) has lowered almost all key parameters of pollution as compared to the dry season, except nitrate and nitrite, which indicated increasing trends during the wet period because runoff also taken animal, human, and poultry wastes dumped in or near the drainage network. Statistically, the variability was significant on the temporal scale and non-significant on the spatial scale-an indication that wastewater contamination is affected by the seasons. If planned properly, the municipal wastewater can be used not only for conserving valuable water resource, but also for taking advantage of the nutrients contained in sewage to grow crops. It is desirable to develop mathematical techniques to aid decision makers in formulating cost-effective and environment-friendly plans and policies for wastewater management. The modeling efforts using SWAT biophysical water quality model would enhance the capability of decision makers in exploring comprehensive and ambitious plans for managing water systems. The adopted approach would provide an effective decision support tool for evaluating better management options to reduce negative impacts of wastewater and contaminants for sustainable agro-environment in future. 


\section{Acknowledgements}

We appreciate the support of the Pakistan Council of Research in Water Resources (PCRWR) for water quality analysis and the field staff of Climate Change, Alternate Energy, and Water Resources Research Institute for rendering valuable assistance while executing this study.

\section{Author details}

Arshad Ashraf, Muhammad Saleem Pomee, Muhammad Munir Ahmad, Muhammad Yasir Waqar and Bashir Ahmad

*Address all correspondence to: mashr22@yahoo.com

Climate Change, Alternate Energy and Water Resources Institute (CAEWRI), National Agricultural Research Center, Islamabad, Pakistan

\section{References}

[1] Li Y, Huang G, Huang Y, Qin X. Modeling of water quality, quantity, and sustainability. Journal of Applied Mathematics Vol. 2014 (2014), Article ID 135905. 3p. http:// dx.doi.org/10.1155/2014/135905.

[2] Beck MB, Reda A. Identification and application of a dynamic model for operational management of water quality. Water Science \& Technology. 1994; 30(2): 31-41.

[3] Wrede S, Seibert J, Uhlenbrook S. Distributed conceptual modelling in a Swedish lowland catchment: a multi-criteria model assessment. Hydrology Research. 2012; (published on-line) DOI:10.2166/nh.2012.056.

[4] Daloğlu I, Nassauer JI, Riolo R, Scavia D. An integrated social and ecological modeling framework -impacts of agricultural conservation practices on water quality. Ecology and Society. 2014; 19(3): 12. http://dx.doi.org/10.5751/ES-06597-190312.

[5] Zhang W, Jia Q, Chen X. Numerical Simulation of Flow and Suspended Sediment Transport in the Distributary Channel Networks. Journal of Applied Mathematics Vol. 2014 (2014), Article ID 948731, 9p. http://dx.doi.org/10.1155/2014/948731

[6] Veldkamp A, Verburg PH. Modelling land use change and environmental impact. Journal of Environmental Management. 2004; 72(1-2): 1-3.

[7] Levin S, Xepapadeas T, Crépin AS, Norberg J, de Zeeuw A, Folke C, Hughes T, Arrow K, Barrett S, Daily G, Ehrlich P, Kautsky N, Maler KG, Polasky S, Troell M, Vincent JR, Walker B. Social-ecological systems as complex adaptive systems: modeling 
and policy implications. Environment and Development Economics. 2012; 18(2): 111-132.

[8] Nesmerak I, Blazkova SD. Analysis of the time series of waste water quality at the inflow of the wastewater treatment plant and transfer functions. Journal of Hydrology and Hydromechanics. 2014; Vol. 62(1): 55-59. DOI: 10.2478/johh-2014-0009.

[9] Malik S. Rawal dam floating on Garbage. Published in Daily Times on December 28, 2005.

[10] Sobia. Determination of Pesticide Residues in Rawal and Simly Lake, A thesis submitted to fulfill partial requirement of degree of Masters in Environment in Department of Environmental Sciences, Fatima Jinnah Women University, Rawalpindi, Pakistan; 2007.

[11] Ahmad I, Anwer MD, Ahmad Z. Reservoir Water Quality Monitoring in Rawal Lake using Geoinformatics. Pakistan Journal of Science. 2012; 64(1).

[12] Ashraf A, Ahmad Z. Integration of Groundwater Flow Modeling and GIS, in Water Resources Management and Modeling, Dr. Purna Nayak (Ed.), ISBN: 978-953-51-0246-5. InTech; 2012. p. 239-262.

[13] Yasin A. Rawal Lake Water Purification. An editorial published in Daily Times on August 20, 2009.

[14] Ashraf A, Naz R, Syial AW, Ahmad B, Yasin M, Saleem M. Assessment of landuse change and its impact on watershed hydrology using remote sensing and SWAT modeling techniques. Int. Jour of Agri. Sc. and Tech. 2014; 2(2): 61-68. DOI: 10.14355/ ijast.2014.0302.02.

[15] Arnold JG, Srinivasan R, Muttiah RS, Williams JR. Large area hydrologic modeling and assessment - Part 1: Model development. Journal of the American Water Resources Association. 1998; 34(1): 73-89.

[16] Arabi M, Frankenberger JR, Enge BA, Arnold JG. Representation of agricultural conservation practices with SWAT. Hydrological Processes. 2008; 22(16): 3042-3055.

[17] Neitsch SL, Arnold JG, Kiniry JR, Williams JR. Soil and water assessment tool (SWAT) theoretical documentation. Texas A\&M University, College Station, Texas, USA. 2011.

[18] Ribaudo MO, Smith, MM. Water quality: impacts of agriculture. In AH-722. Agricultural Resources and Environmental Indicators. Economic Research Service, USDA, Washington, D.C., USA. 2000.

[19] Boyer EW, Goodale CL, Jaworsk NA, Howarth RW. Anthropogenic Nitrogen sources and Relationships to Riverine Nitrogen export in the Northeastern USA. Biogeochemistry. 2002; 57(1): 137-169.

[20] Galloway JN, Dentener FJ, Capone DG, Boyer EW, Howarth RW, Seitzinger SP, Asner GP, Cleveland CC, Green PA, Holland EA, Karl DM, Michaels AF, Porter JH, 
Townsend AR, Vöosmarty C J. Nitrogen cycles: past, present, and future. Biogeochemistry. 2004; 70(2): 153-226.

[21] Shafiq M, Ahmed S, Nasir A, Ikram MZ, Aslam M, Khan M. Surface runoff from degraded scrub forest watershed under high rainfall zone. Journal of Engineering and Applied Sciences. 1997; 16(1): 7-12.

[22] Aftab N. Haphazard colonies polluting Rawal Lake, Daily Times Monday, March 01, 2010. http://www.dailytimes.com.pk/default.asp...009_pg11_1.

[23] Ghumman AR. Assessment of water quality of Rawal Lake by long-time monitoring. Environ Monitoring and Assessment. 2010; 180: 115-126.

[24] PEPA (Pakistan Environmental Protection Agency). Report on Rawal Lake Catchment Area Monitoring Operation. Ministry of Environment, Islamabad, Pakistan. 2004: p.19.

[25] Dolan DM, Chapra SC. Great Lakes total phosphorus revisited: 1. Loading analysis and update (1994-2008). Journal of Great Lakes Research. 2012; 38(4): 730-740.

[26] Saeed MA, Ashraf A, Ahmad B, Shahid M. Monitoring deforestation and urbanization growth in Rawal Watershed area using Remote Sensing and GIS techniques. Jour of COMSATS- Science Vision. 2011; Vol. 16\&17: 93-104.

[27] IUCN. Rapid environmental appraisal of developments in and around Murree Hills, IUCN Pakistan. 2005.

[28] Hawley N, Johengen TH, Rao YR, Ruberg SA, Beletsky D, Ludsin SA, Brandt SB. Lake Erie hypoxia prompts Canada-U.S. study. Eos, Transactions of the American Geophysical Union. 2006; 87(32): 313-319.

[29] Zhou Y, Obenour DR, Scavia D, Johengen TH, Michalak AM. Spatial and temporal trends in Lake Erie hypoxia, 1987-2007. Environmental Science and Technology. 2013; 47(2): 899-905. http://dx.doi.org/10.1021/es303401b.

[30] Scavia D, Allan JD, Arend KK, Bartell S, Beletsky D, Bosch NS, Brandt SB, Briland RD, Daloğlu I, DePinto JV, Dolan DM, Evans MA, Farmer TM, Goto D, Han H, Höök TO, Knight R, Ludsin SA, Mason D, Michalak AM, Richards RP, Roberts JJ, Rucinski DK, Rutherford E, Schwab DJ, Sesterhenn T, Zhang H, Zhou Y. Assessing and addressing the re-eutrophication of Lake Erie: Central basin Hypoxia. Journal of Great Lakes Research. 2014; 40(2): 226-246.

[31] Carpenter SR. Phosphorus control is critical to mitigating eutrophication. Proceedings of the National Academy of Sciences of the United States of America. 2008; 105(32): 11039-11040. DOI:10.1073/pnas.0806112105.

[32] Vesilind AP. Wastewater Treatment Plan Design. A book published in Water Environment Federation. 2003. 
[33] University of Minnesota publication. Onsite Sewage Treatment Plant - Wastewater Sources and Flows. Water Resource Center. 2011.

[34] The Government Gazette of National Environmental Quality Standards (NEQS). Government of Pakistan. 2000.

[35] Kahlown MA, Ashraf M, Hussain M, Abdul Salam H, Bhatti AZ. Impact assessment of sewerage and industrial effluents on water resources, soils, crops and human health in Faisalabad. A report published by Pakistan Council of Research in Water Resources (PCRWR), Islamabad, Pakistan. 2006: p.110.

[36] Nassauer JI, Corry RC. Using Normative scenarios in Landscape Ecology. Landscape Ecology.2004; 19 (4): 343-356.

[37] Siddiqui KM, Mohammad I, Ayaz M. Forest ecosystem climate change impact assessment and adaptation strategies for Pakistan. Climate Research. 1999; 12: 195-203.

[38] Forster DL. Public policies and private decisions: Their impacts on Lake Erie water quality and farm economy. Journal of Soil and Water Conservation. 2000; 55(3): 309-322. 
